\title{
土䁃水分ストレスを考慮した気孔コンダクタンスモデルに関する研究 A STUDY ON STOMATAL CONDUCTANCE MODEL
WITH SOIL MOISTURE STRESS
}

\author{
花平 愛*, 吉田治典** \\ Ai KADAIRA and Harunori YOSHIDA
}

\begin{abstract}
The purpose of this study is 1) to clarify variations in moisture of soil around a tree, 2) to determine parameters of soil moisture stress function by measuring diurnal variations in stomatal conductance of wet soil and dry soil.

The results show that :1)the determined parameters are applicable to estimation of decline in stomatal conductance by soil moisture streess. 2)stomatal conductance declines to around a half of wet soil on fifteen days in a month.
\end{abstract}

Keywords : Stomatal conductance, Jarvis type model, Soil moisture stress , Soil moisture characteristics 気孔コンダクタンス, Jarvis 型モデル，土壌水分ストレス，土㙵水分特性曲線

\section{1. 度}

既報1では, 樹木の気温低減効果は降雨後に大きくなるが, 以後 晴天が続くと徐々に小さくなる,というように降雨との関係が強い ことを示した。これは晴天が続くと土䖯体積含水率が減少し，その 結果, 樹木の蒸散に影響を与えるためと考えられる。従って, 著者らはこれまで先行雨量から考えて土壤が湿潤である場合の 樹木の気候緩和効果の実態を把握し，その効果の定量化を行っ てきた ${ }^{5)}$ が，土塤の水分状態が既に提案した樹木の蒸散モデル にどの程度影響を及ぼすのか検討することは重要である。

気孔の開閉度合いを表す Jarvis 型モデルは, 光合成有効放射, 気温, 飽差, 葉内水ポテンシャル, 大気二酸化炭素浱度の関数 (気孔の閉鎖の要因となるストレス関数)として表されている 2)。しかし，このモデルの提案後，ストレス関数の修正や他の 環境因子が加えられるなど多くの研究者により改良され，近 年, 農学分野や水文学分野では, 環境因子として土㙵水分ポテ

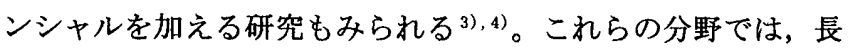
期にわたるマクロスケールでの気候予測や水循環予測を対象之 しているため, 土㗒の水分不足（土壌水分ポテンシャルで表 す）が気孔の閉鎖を誘導し，蒸散を制御するというメカニズム を無視できないからである。例えば, Davies and Zhang ${ }^{4)}$ は, 日
変化レベルでの気孔コンダクタンスの変動は飽差により大きな 影響を受け，季節変化レベルの変動は土壤水分量により大きな 影響を受けることを報告している ${ }^{3)}$ 。

さて，建築分野で考えると，建物周辺の樹木は一般に狭い土 地に植えられることが多く，樹木の蒸散を活発に行うための水 分を持続的に保持できる環境では必ずしもない。しかしなが ら，建築周辺の樹木は完全な自然の状態下に置かれるものでは なく，非常に乾燥すれば，適当な散水管理がなされるものであ る。よって, 土壤の水分不足で樹木の気温低減効果がどれ程減 少するのかを定量的に把握したり, 蒸散による気温低減効果を 持続的に得るための給水管理を行う指標とするために，土壌水 分ポテンシャルを気孔コンダクタンスモデルの環境因子に加え て検討する。そこで，土䗙が湿潤時のモデル5)をもとに，土壤 の水分不足による水分ストレス（土壤が乾燥し始めると，ABA が根から放出され気孔の閉鎖を誘導する $\left.{ }^{6\rangle}\right)$ の関数の変数とし て加えることを考える。

本研究では，実際の常緑樹を対象に，1）土壤の水分状態がど のように変化するのかという実態の把握，2）土壤の乾燥時と湿 潤時における気孔コンダクタンスの日変化を実測し，土壤が湿 潤である時のモデルに土壤の水分状態（土壤水分ポテンシャ

\footnotetext{
本研究の一部は, 2006年度日本建築学会大会(関東)听おいて発表した。

* 元 京都大学大学院工学研究科眇境地球工学専攻 博士 (工学)

** 京都大学大学院工学研究科都市環境工学専攻 教授・工博
}

Graduate Student, Dept. of Global Environment Eng., Faculty of Eng., Kyoto University, Dr. Eng.

Prof., Dept. of Urban and Environmental Eng., Faculty of Eng., Kyoto University, Dr. Eng. 


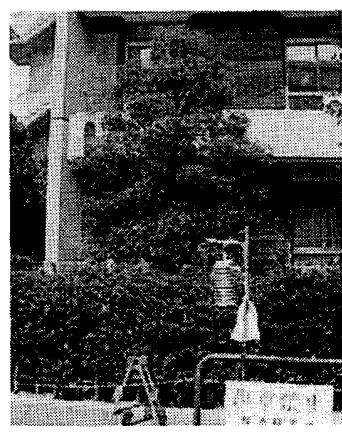

写基1 対象樹

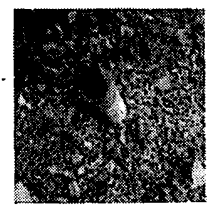

写兵2 土㙥体積含水率の測定
ル）を環境因子に加え，このストレス関数のパラメーターの決 定，3）このストレス関数と土培の水分ストレスのないものの関 数とを比較し，土袞水分ポテンシャルを導入する必要性の検討 を目的とする。

\section{2. 实測概要}

京都市左京区に立地する大学内の常緑樹(モッコク;ツバキ科)を 実測対象とした。実測地は 4 階建て研究棟の南側壁面から約 $5 \mathrm{~m}$ 離れた位置に植えられたモッコクの周辺である注1)。垣根で囲 まれた $4 \mathrm{~m}$ 幅の裸地に樹木が植えられ，定期的に手入れされて おり，集合住宅の緑地に近い環境と考えて選定した。また， モッコクは住宅によく用いられるといわれる樹種である。実測 地の南側はアスファルトで被覆され，前方の建物は $15 \mathrm{~m}$ 以上離 れて，日射を遮蔽することはない。樹高は $4.0 \mathrm{~m}$ で主幹 $0.2 \mathrm{~m}$ ，半 径 $1.2 \mathrm{~m}$ の枝張りである。対象樹を写真 1 に示す。

気孔コンダクタンスは 2005 年 8 月 29 日，9月 9 日，12日，土 境体積含水率は 2005 年 8 月 19 日〜 9 月 20 日に実測し，また， $8: 30 \sim 18: 00$ に定点で光合成有効放射, 気温, 絶対湿度を 1 分間隔で連続測定し，移動実測では気孔コンダクタンスを 1 時 間ごとに測定した。土壌体積含水率は 5 分間隔で，30日間連続 測定した。なお，ポロメータは，湿度センサーを葉面に密着さ せて葉からの蒸散によってキュベット内空気が設定した相対湿 度に達する時間を測定して気孔コンダクタンスに換算する。飽 差は携帯型温湿度計により測定した絶対湿度と気温または，葉 面に密着する部分に設置されたポロメータの温度センサーによ り測定した菄温を用いて求めた。

光合成有効放射の計測面は気孔コンダクタンスを測定する葉と 同じ傾きとした。以上まとめて, 測定項目を表 1 に, 測定位置 を図 1，2に示す。ただし，降雨量は大学構内の屋上で測定した。 気孔コンダクタンスはポロメータを用いて測定し，測定葉は

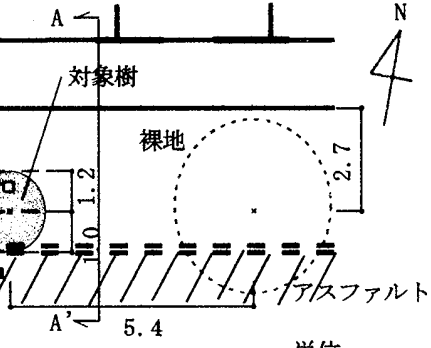

図1 実測位置(平面)
単位 : $m$

\section{衰1 測定項目並びに使用した測定機器}

\begin{tabular}{|c|c|c|c|c|c|}
\hline 湖定項目 & 祀景 & 点数 & 溻定譏器 & 测定高さ[m] & 㴬定間隔[分] \\
\hline 気温 & $T$ & 1 & 㩲带型晹湿度㖕 & 1 & 1 \\
\hline 䎦対湿度 & $X$ & 1 & 撞带型温湿度計 & 1 & 1 \\
\hline 鞂れコンダクタンス & $g_{S}$ & 3 & ポロメータ(Delta-T社) & 1.5 & - \\
\hline 光合成有効放射 & $Q$ & - & 光量子センサー & 1.5 & 1 \\
\hline 土境体䅡含水事 & $\theta$ & 2 & シータープロープ & $-0.1,-0.3$ & 5 \\
\hline
\end{tabular}

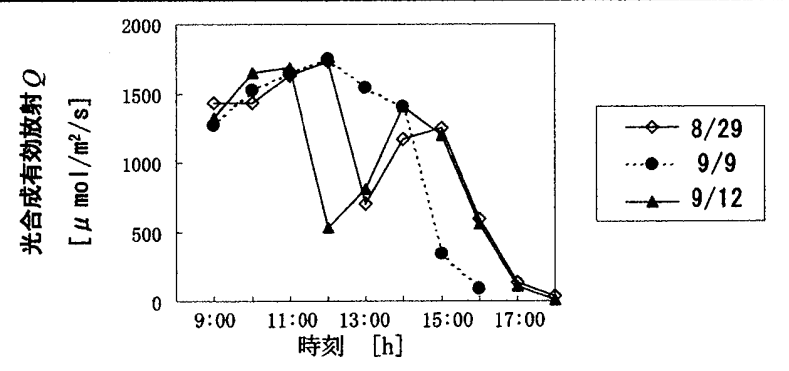

(a) $Q$ の経時変化

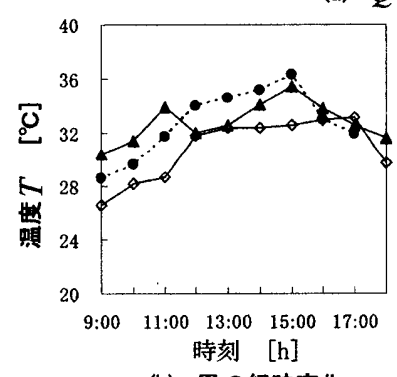

(b) $T$ の経時変化

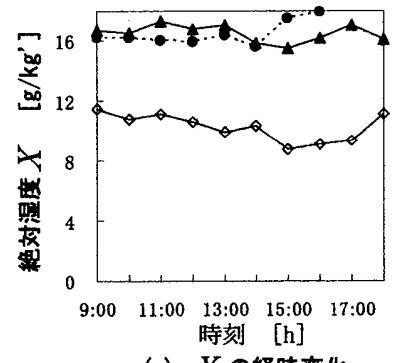

(c) $X$ の経時変化
図 $3 Q, T, X$ の経時変化 $(8 / 29,9 / 9,9 / 12)$

南面にある $\mathrm{GL}+1.5 \mathrm{~m}$ 付近の葉面の傾きが同じとなる 3 枚を選ん だ。土袞体積含水率のセンサーは GL-0.1m，-0.3mに埋設した (写真 2)。これは, 一般に水分や養分を吸収する細い根（吸収 根）は表層土に多く，地表から $-0.3 \sim-0.6 \mathrm{~m}$ 付近で吸収根は特 によく分布するといわれるからである7)。実測地においても，$0.3 \mathrm{~m}$ 附近に細い根がみられた。GL-0.3m のセンサーは実測の 9 ケ月前に, GL-0.1mのセンサーは 8 月 16 日（測定の 12 日前）に 埋設した。
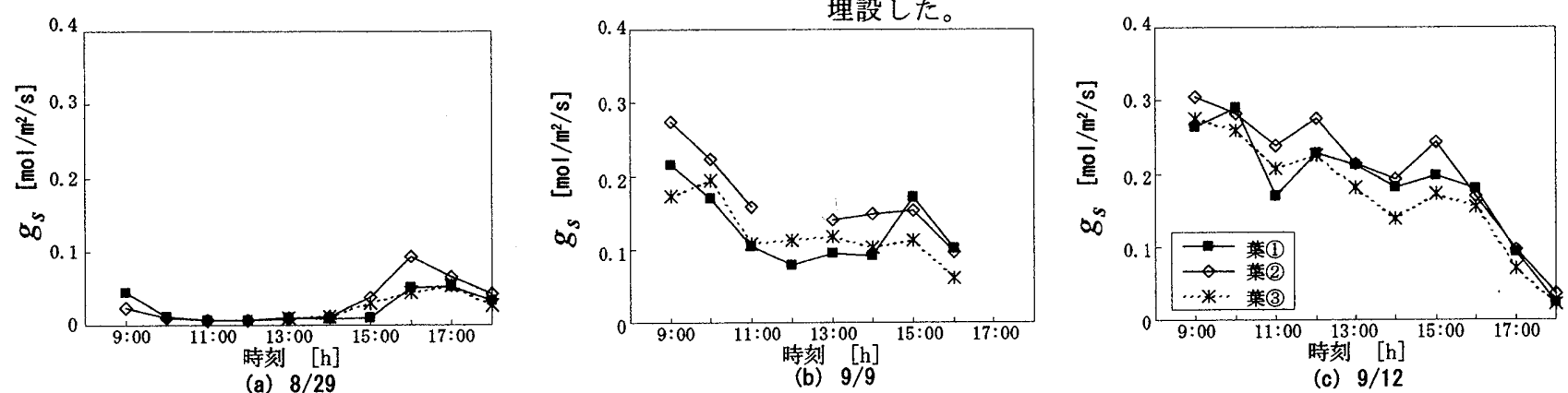

図 $4 g_{s}$ の経時変化 $(8 / 29,9 / 9,9 / 12)$ 

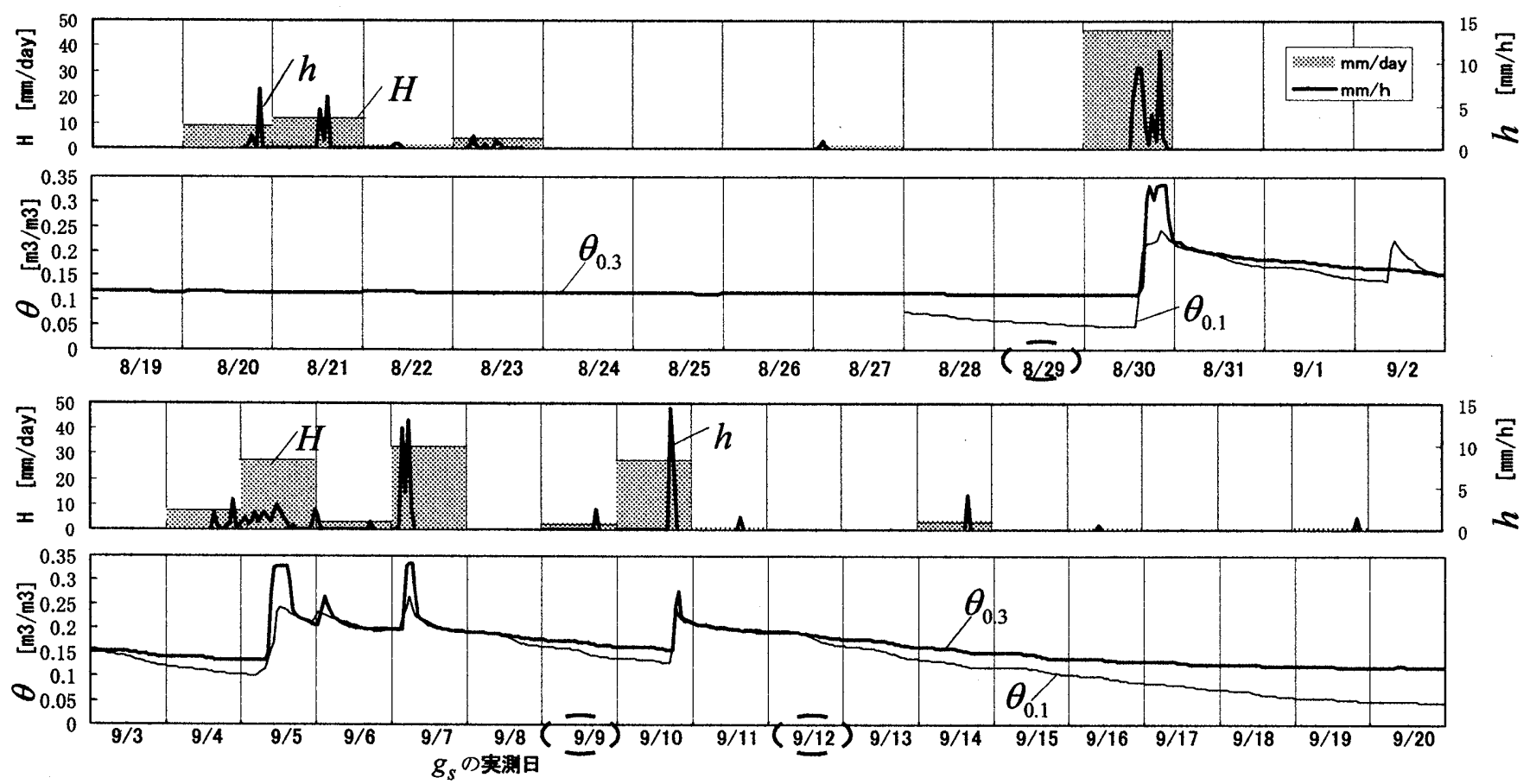

图 5 日積算降雨量と $\theta$ の経時変化 $(8 / 19 \sim 9 / 20) \quad$ ） は $g_{s}$ の実測日を示す

\section{3.気象条件と気孔コンダクタンスの経時変化}

8 月 29 日の前 10 日間の積算降雨量は $27 \mathrm{~mm}$ と少ないが，9月 9 日には $71 \mathrm{~mm}, 9$ 月 12 日には $102 \mathrm{~mm}$ と多量の降雨があった。図 3 に 8 月 29 日, 9 月 9,12 日の光合成有効放射 $Q$, 気温 $T$, 絶対 湿度 $X$ の経時変化を示す。図の値は, 5 分間平均值の $T, X, Q$ である。図より, $T$ は $25 \sim 36^{\circ} \mathrm{C}, X$ は $9 \sim 18 \mathrm{~g} / \mathrm{kg}$ 'の範囲にあ り，8月 29 日の $T$ は 3 日間で最も低く, $X$ も他の 2 日間より $2 \mathrm{~g} /$ $\mathrm{kg}$ ’小さい。 $Q$ は 3 日間ともピーク時には約 $1,800 \mu \mathrm{mol} / \mathrm{m}^{2} / \mathrm{s}$ と 大きい。

図 4 に 8 月 29 日，9月 9 日，9月 12 日の 3 日閒の $g_{s}$ の経時変 化を示す。 $g_{s}$ は测定葉 3 枚をプロットする。

図 4(a)より，8月 29 日の $g_{s}$ は，日中にはほぼ $0 \mathrm{~mol} / \mathrm{m}^{2} / \mathrm{s}$ と なり，日中に低下し特異である。9月 9 日は 16 時以降に夕立が あり，実測值の欠損があるが，8月 29 日よりも $g_{s}$ は大きいこ とが判る（図 4(b))。9 月 12 日の $g_{s}$ は午前中に約 $0.3 \mathrm{~mol} / \mathrm{m}^{2} / \mathrm{s}$ と大きく, $g_{s}$ の日変化は午後に向かって単調に減少する（図 4 (c) $)$ 。

8 月 29 日の $g_{s}$ が他の日と比べて小さい原因は 2 つ考えられ る。1） $X$ が低いために飽差が增大し気孔が閉じたため6)，2）土 壤の乾燥による水分ストレスが要因となって気孔が閉じたた め。2)の場合， $g_{s}$ は徐々に低下し，土壤が乾燥すればする程， 日中の低下は大きくなるといわれている ${ }^{6)}$ (appendix1 参照)。こ の点については 5,7 節で検討を行う。

\section{4.土燷体積含水率の経時変化}

降雨量と土壤体積含水率 $\theta$ との関係を検討する。以後, $-0.3 \mathrm{~m}$ の $\theta$ を $\theta_{0.3},-0.1 \mathrm{~m}$ の $\theta$ を $\theta_{0.1}$ と表す。図 5 に日積算降雨量 $H$ と 1 時間積算降雨量 $h, \theta_{0.1}$ と $\theta_{0.3}$ の経時変化を示す。 $\theta$ の值は各時 刻の前後 30 分の 1 時間平均である。図より, 以下のことが判る。
1) 降雨の少ない日が続いた 8 月 29 日は $\theta_{03}\left(0.13 \mathrm{~m}^{3} / \mathrm{m}^{3}\right)>\theta_{01}$ $\left(0.06 \mathrm{~m}^{3} / \mathrm{m}^{3}\right)$ となるが, 降雨後の 9 月 12 日には $\theta_{0.1}$ と $\theta_{0.3}$ は ほぼ同じとなる。

2 ) 降雨時には $\theta_{0.3}$ が急激に大きくなる。降雨後の減少率は $\theta_{0.3}$ より $\theta_{0.1}$ の方が大きい。つまり，地表面に近い $-0.1 \mathrm{~m}$ の方が 乾燥状態になりやすいといえる。

3）日積算降雨量が $10 \mathrm{~mm} /$ day 程度では, $\theta$ は $-0.3 \mathrm{~m},-0.1 \mathrm{~m}$ ともに変 化が確認できない。

4) 8 月 29 日における $\theta_{0.3}$ と $\theta_{0.1}$ は約 $0.1 \mathrm{~m}^{3} / \mathrm{m}^{3}$, 約 $0.05 \mathrm{~m}^{3} / \mathrm{m}^{3}$ 程度 で，降雨後の $\theta$ と比べてかなり小さく，乾燥している。

\section{5. 常緑樹のパラメータを用いた推定結果}

$g_{s}$ の日中の低下が土壌の乾燥によるのではなく, $X$ が低く 飽差が增大したためであれば, $Q, T$ ，飽差 $D[\mathrm{kPa}]$ のつを環 境因子とする気孔コンダクタンスモデルで $g_{s}$ が推定できるは ずである。そこで，推定した $g_{s_{-} s i m}$ と実測值 $g_{s_{-} \text {real }}$ の日変化を 比較検討する。

既報8)では，同じ樹木に対して土壤の水分ストレスがないと して, (1) 〜 (4) 式に示す気孔コンダクタンスモデルに含まれる 5 つのパラメータ $g_{s \max }, a, T_{0}, b_{1}, b_{2}$ を観測値を用いて同定した。 それを再録する。

$$
\begin{aligned}
& g_{s}=g_{s \max } f_{q}(Q) f_{t}(T) f_{d}(D) \\
& g_{s \max } f_{q}(Q)=\frac{g_{s \max } Q}{Q+g_{s \max } / a}
\end{aligned}
$$

$$
f_{t}(T)=\left(\frac{T-T_{l}}{T_{o}-T_{l}}\right)\left\{\left(\frac{T_{h}-T}{T_{h}-T_{o}}\right)\left(\frac{T_{h}-T_{o}}{T_{o}-T_{l}}\right)\right\}
$$



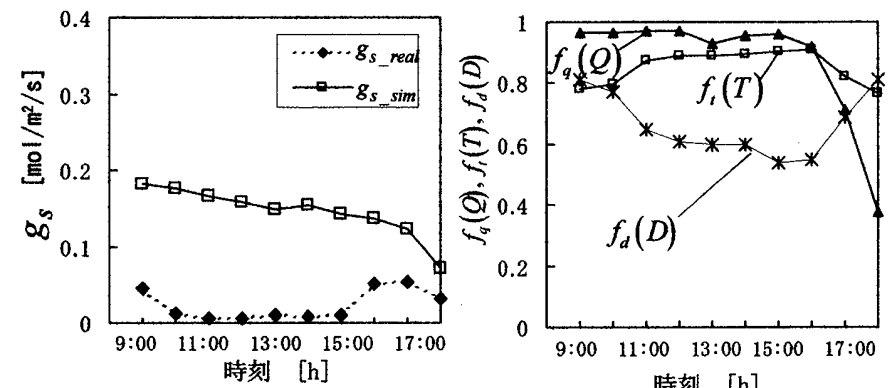

(a) $8 / 29$

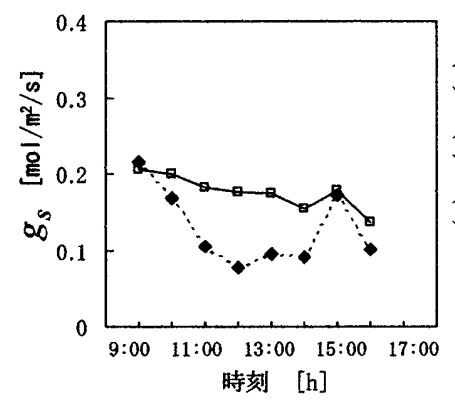

(b) $9 / 9$
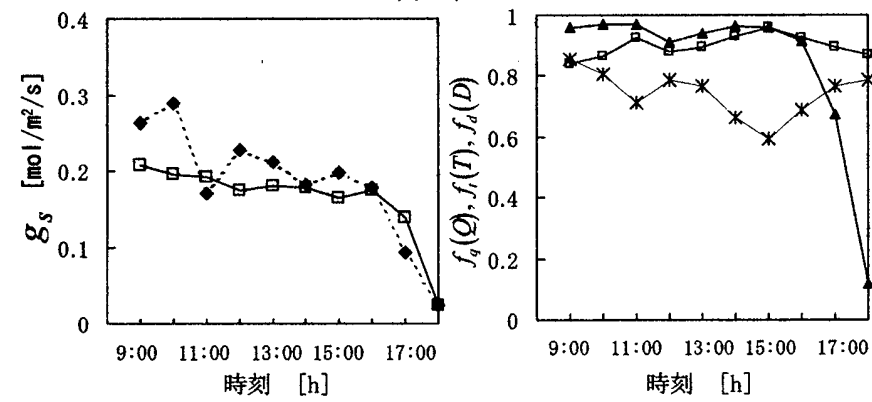

(c) $9 / 12$

図 $6 g_{s_{-} s i m}$ と $g_{s_{-} \text {real }}$ の経時変化 $(8 / 29,9 / 9,9 / 12)$

衰2 モッコクのパラメータ

\begin{tabular}{|c|c|c|c|c|c|c|}
\hline$g_{s \max }$ & $a$ & $T_{l}$ & $T_{0}$ & $T_{h}$ & $b_{1}$ & $b_{2}$ \\
\hline 0.30 & 0.0057 & 5 & 39.0 & 42 & 3.93 & 2.09 \\
\hline
\end{tabular}

$$
f_{d}(D)=\frac{1}{1+\left(D / b_{1}\right)^{b_{2}}}
$$

ここで, $g_{s \max }$ : 最大気孔コンダクタンス $\left[\mathrm{mol} / \mathrm{m}^{2} / \mathrm{s}\right], a:$ 光に よって気孔が開く反応の効率 $[-], T_{o}$ : 最適温度 $\left[{ }^{\circ} \mathrm{C}\right], T_{l}$ : 最低限 界温度 $\left[{ }^{\circ} \mathrm{C}\right], T_{h}$ : 最高限界温度 $\left[{ }^{\circ} \mathrm{C}\right], b_{1}$ : 気孔コンダクタンスが 半分になる飽差の値 $[-], b_{2}:$ 曲率 $[-]$

このパラメータ（表 2）を用いて，8 月 29 日，9月 9，12 日の $g_{s}$ を推定した。なお,

著者らはこれまで, 気 温と葉温の差は小さい として，葉温ではな く, 気温で葉面の飽和 水蒸気圧を推定してき た $\left(g_{s_{-} \text {sim }}\right)$ 。しかし, 8 月 29 日には気温より

葉温が最大で $6 \mathrm{~K}$ 高い

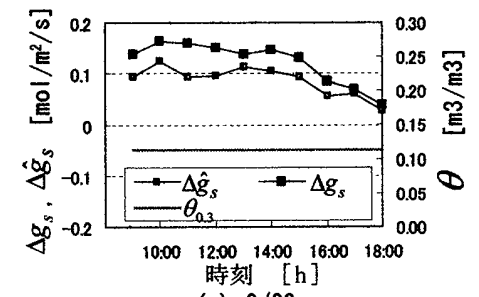

(a) $8 / 29$
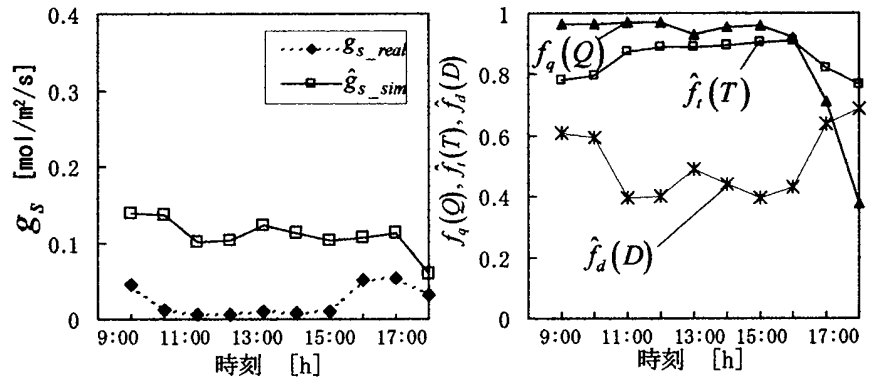

(a) $8 / 29$
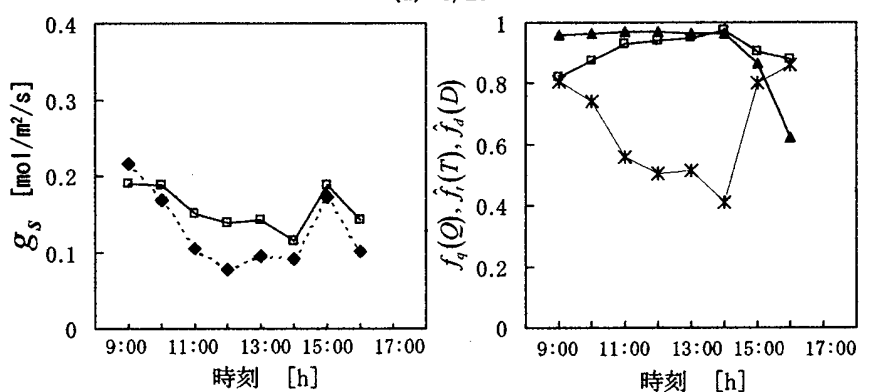

(b) $9 / 9$

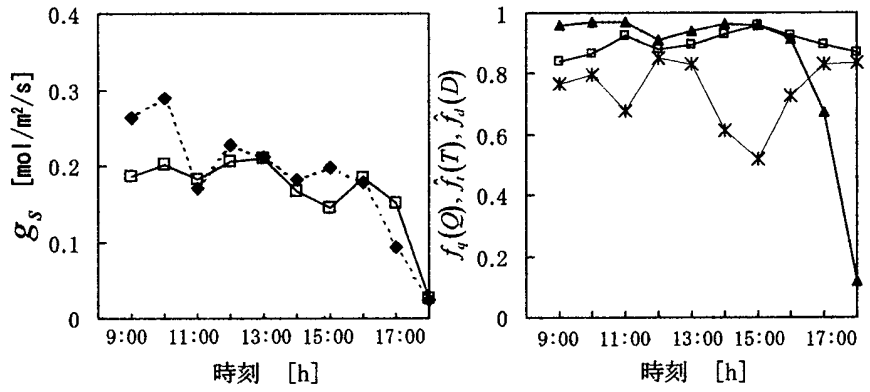

(c) $9 / 12$

图 $7 \hat{g}_{s_{-} s i m}$ と $g_{s_{-} \text {real }}$ の経時変化 $(8 / 29,9 / 9,9 / 12)$

ため，本報では, (3) 式の $T$ は葉温，(4) 式の飽差は葉温を用いて 求めたもの $\left(\hat{g}_{s_{-} s i m}\right)$ も比較検討する。各実測日の気温の飽和水 蒸気圧を用いた $g_{s_{-} s i m}$ と $g_{s_{-}}$real を図 6 に, 葉温の飽和水蒸気圧 を用いた $\hat{g}_{s_{-} s i m}$ と $g_{s_{-} \text {real }}$ を図 7 に示す。図 8 に $g_{s_{-} \text {real }}$ と $g_{s_{-} s i m}$ の差 $\left(\Delta g_{s}\right), g_{s_{-} \text {real }}$ と $\hat{g}_{s_{-} s i m}$ の差 $\left(\Delta \hat{g}_{s}\right), \theta_{0.3}$ との関係を示す。

気温を用いた場合も葉温を用いた場合も，9月12 日の実測值 と推定結果はほぼ一致するが，8 月 29 日の一致度は悪い。図 8 より，8月 29 日の $\Delta g_{s}$ と $\Delta \hat{g}_{s}$ はともに 9 月 12 日より大きく, $\theta_{0.3}$ の減少と関傒が強いことが判る。よって，この不一致は飽差の 増大ではなく，土壤の水分減少による気孔閉鎖（ストレス）に 起因すると考えざるを得ない。また，8月 29 日と 9 月 9 日の 11 $\sim 14$ 時頃における $g_{s_{-} \text {sim }}$ は $g_{s_{-} \text {real }}$ より大きくなるが，9月 12 日 の $g_{s_{-} \text {sim }}$ および $\hat{g}_{s_{-} s i m}$ は $g_{s_{-} \text {real }}$ と差がほとんどない。これは， 8 月 29 日の $f_{d}(D)$ が $\hat{f}_{d}(D)$ より大きいためである。

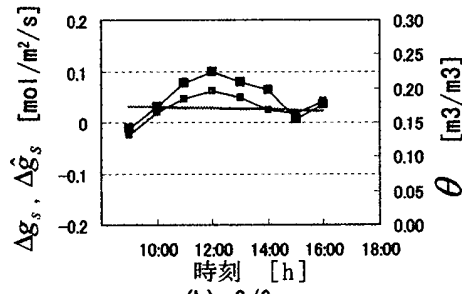

(b) $9 / 9$

図 $8 \Delta g_{s}, \Delta \hat{g}_{s}, \theta_{0.3}$ との関係 $\quad(8 / 29,9 / 9,9 / 12)$

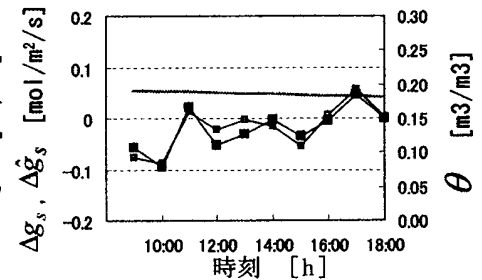

(c) $9 / 12$ 


\section{6. 土壤水分特性曲緗の定式化}

気孔コンダクタンスモデルに土壤の水分状態を考慮するため に, $\theta$ を土壤の水分ポテンシャル $\psi$ に変換し, Jarvis 型モデルに 組み込んだモデルが提案されている。 $\theta$ と $\psi$ の関倸（土培水分 特性曲線）を表す関数型には次の van Genuchten(1980)の式帛が 用いられる。

$$
\theta=\theta_{r}+\left(\theta_{s}-\theta_{r}\right)\left[1+(\alpha \psi)^{n}\right]^{-m}
$$

ここで, $\psi$ :水分ポテンシャル $\left[\mathrm{cmH}_{2} 0\right], \theta_{r}$ : 残留体積含水率 $\left[\mathrm{m}^{3} / \mathrm{m}^{3}\right], \theta_{s}$ : 最大体積含水率 $\left[\mathrm{m}^{3} / \mathrm{m}^{3}\right], \alpha, n:$ 土埣に固有のパラ メータ, $m=1-\frac{1}{n}$

$\theta$ と $\psi$ の関係は土壤の構造によって異なるため，実測地の土 袞を採土して，実験で $\psi$ を変化させた時の $\theta$ を測定し，（5）式

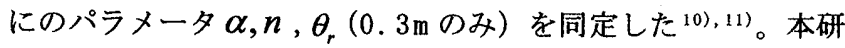
究では, 対象樹の幹から $0.7 \mathrm{~m}$ 離れた地点の樑さ $0.1 \mathrm{~m}, 0.3 \mathrm{~m}$ で 土袞体積含水率を測定したため, 各深さで $100 \mathrm{~cm}^{3}$ の土樭サンプ ルを 3 つ採土した。このサンプルに土柱法, 吸引法, 遠心法, 蒸気圧法の 4 つの方法を適用し， $\theta$ と $\psi$ の関係を求めた（図 9 及 び appendix2 参照)。

各深さとも土壤サンプルを飽和状態にした時に，体積が減少 しない密度で採土できたのは，2つのサンプルのみであったの でこの $2 つ の \theta$ を平均し, 非線形最小二乗法を用いてパラメー 夕を同定した注2)。同定に蹬し，初期值は既往研究 ${ }^{12)}$ を参考に して定めた。同定した結果を表 3 に示す。なお, $\theta_{s}$ およびー $0.1 \mathrm{~m}$ の $\theta_{r}$ は実験で求めた（表 4 参照）。

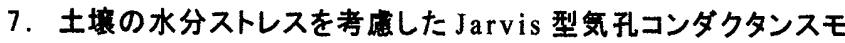
テル

5 節の推定結果の差が，土㙵水分状態を考慮した場合にどの ように影響するのか検討を行う。

ここで用いる気孔コンダクタンスモデルは, (1) 式に土㙵水分 に関するストレス関数 $f_{\psi}(\psi)$ を乗じた（6）式である ${ }^{13)}$ 。

「気孔の閉鎖には，飽差の増大により蒸散が活発になって葉 内水分が減少する，あるいは土袞水分の減少により葉内水分が 减少してこれらが信号となって気孔が閉鎖する feedback 反忘が あるが，飽差の增大および土壌水分ポテンシャルの低下が直接 信号となって気孔が閉鎖する feedfoward 反応も知られている 14)」。本研究では，気孔開閉に関する植物生理学的知見を踏ま えて提示されたモデル13)，14）を用いる。

$$
g_{s \psi}=g_{s \max } f_{q}(Q) f_{t}(T) f_{d}(D) f_{\psi}(\psi)
$$

ここで, $f_{\psi}(\varphi)$ : 土壤の水分ポテンシャルに関するストレス関数

$f_{\psi}(\psi)$ は, Hanan and Prince $(1997)^{15)}$ が提示している次式を用い る。なお, $f_{\psi}(\psi)$ は $0 \sim 1$ の値をとる。

$$
f_{\psi}(\psi)=1-\frac{\psi_{\max }-\psi}{\psi_{\max }-c}
$$

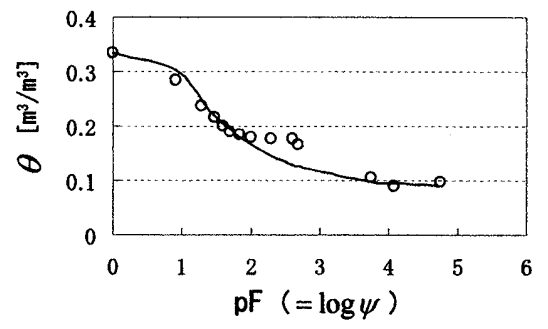

(a) $-0.3 \mathrm{~m}$

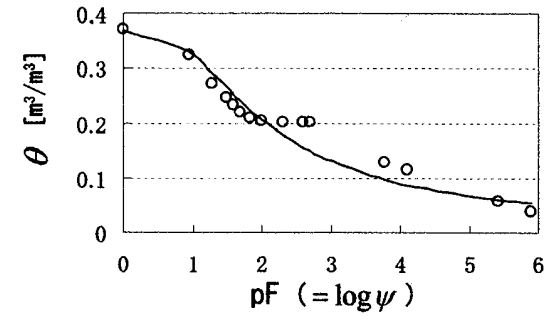

(b) $-0.1 \mathrm{~m}$

図 9 土壤水分特性曲線の推定結果

丧3 パラメータの同定結果

\begin{tabular}{|c|c|c|c|c|}
\hline & $\theta_{r}$ & $\alpha$ & $n$ & $m$ \\
\hline$\theta_{0.1}$ & - & 0.134 & 1.78 & 0.1474 \\
\hline$\theta_{0.3}$ & 0.083 & 0.145 & 2.89 & 0.1431 \\
\hline
\end{tabular}

表4 実験で求めた値

\begin{tabular}{|c|c|c|}
\hline & $\theta_{r}$ & $\theta_{s}$ \\
\hline$\theta_{0.1}$ & 0.038 & 0.37 \\
\hline$\theta_{0.3}$ & - & 0.334 \\
\hline
\end{tabular}

ここで, $\psi$ : 土境水分ポテンシャル $\left[\mathrm{cmH}_{2} \mathrm{O}\right], \psi_{\max }$ : 煵場 容水量時注 31 の土壤水分ポテンシャル $\left[\mathrm{cmH}_{2} \mathrm{O}\right], c$ : 常数

$\psi_{\max }>\psi>c$ という条件を満たすことが必要とされており， 既往研究 ${ }^{3)}$ にならい， $\psi_{\max }$ は $-39 \mathrm{cmH}_{2} \mathrm{O}$ とする。 $\psi$ は $\theta_{0.3}$ を $\psi$ に変換した值を用いる。なお，常数 $c$ は気孔が閉じる際の土壤 水分ポテンシャルである。 $f_{q}(Q), \hat{f}_{t}(T), \hat{f}_{d}(D)$ の関数のパラメー タは 5 節で用いたものとし $f_{\psi}(\psi)$ のパラメータのみ同定する。 また, 既往研究 ${ }^{3)}$ を参考にして, $c=-2000 \mathrm{cmH}_{2} \mathrm{O}$ を初期値とし て同定した。8月 29 日の 3 枚の各葉の実測值を一つのデータ セットとして, $T$ は葉温, $D$ は葉温の飽和水蒸気圧を用いて $\left(g_{s \psi_{-} s i m}\right)$, パラメータ $c$ の同定を行った。同定した結果, $c$ の值 は-1578 $\mathrm{cmH}_{2} \mathrm{O}$ となった。Hanan らの報告 ${ }^{15}$ によれば, $c$ の值 は-1192〜-3514 $\mathrm{cmH}_{2} \mathrm{O}$ とされていることから妥当な值と考え られる。

同定したパラメータを用いて推定した $g_{s \psi_{-} s i m}$ と $g_{s_{-} \text {real }}$ の比 較，ならびに $f_{\psi}(\psi), \hat{f}_{d}(D)$ のストレス係数（8月29日，9月9日，

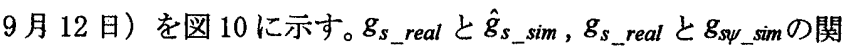
係（8月 29 日，9月9日）を図 11 に示す。

図 $10(\mathrm{a})$ ，図 11 より, $g_{s \psi_{-} s i m}$ は $f_{\psi}(\psi)$ を考虑しない場合より $g_{s_{-} \text {real }}$ と一致することが判る。 8 月 29 日の $g_{s_{-} \text {real }}$ の低下は, 土 壤水分ポテンシャルに関するストレス関数を掛けたモデルで推 定するとおおむね再現できるといえる。

8月 19 日〜9月 20 日の $c$ を用いて推定したストレス係数 $f_{\psi}(\psi)$ 
の経時変化の検討を行う。図 $12 k f_{\psi}(\psi)$ の経時変化を示す。 図より，今回の実測によれば，土壤の乾燥によるストレス係 数 $f_{\psi}(\psi)$ が 0.5 以下となる日は 15 日であった。晴天で $\hat{f}_{r}(T)$ が約 $0.8 \sim 1.0, \hat{f}_{d}(D)$ が約 $0.6 \sim 0.9$ の範囲と仮定すれば, 気孔コン ダクタンスは $f_{\psi}(\psi)$ と比例するので, 蒸散が $1 / 2$ 以下に抑制さ れるのは15 日といえる。

\section{8. 結諭}

本報では，常緑樹を対象に，1）樹木周辺の土壤の水分状態が どのように变化するのか実態を把握すること，2）土壤が乾燥状 態の時と湿潤状態の時での気孔コンダクタンスの日変化の実測 を行い，士㙥の水分状態を環境因子に加えて，土壌水分に関す るストレス関数のパラメーターを決定することを目的とした。 得られた結論を以下に示す。

1）実測地の土㙥体積含水率とマトリックポテンシャルとの関 数関係を表した土壤水分特性曲線を求めて定式化した。

2) 気孔コンダクタンスモデルに土壇の水分ストレス関数を加 え，ストレス関数のパラメータを決定し，このパラメータを 用いて推定した結果, 土䘫の水分ストレスによる気孔コンダ クタンスの低下がおおうむね再現できた。

3) 今回の実測結果をもとに土壤水分ストレスを推定した場合, 土㙵が乾燥すれば気孔コンダクタンスが $1 / 2$ 程度に減ずるの は比較的乾燥した真夏 1ヶ月（8月19日〜9月 20 日）のうち 15 日であった。

本報で，乾燥時には土韹水分に関するストレス関数 $f_{\psi}(\psi)$ を モデルに組み込まなければ精度の良い乾燥時のモデルは得られ ないことを示した。このことは樹木の蒸散を期待するために乾 燥時の散水が不可欠であることを意味している。つまり，給水 管理を行うことを前提とした建物周辺の植栽計画を行い，乾燥 時を考虑しないで検討するのが緑化設計の立場と考える。な お, $f_{\psi}(\psi)$ をモデルに組み入れるためには, 葉温と土䖯水分ポテ ンシャルを推定するモデルの開発が必要である。これは, 今後 の課題としたい。

\section{期辞}

本研究を行うにあたり, 京都大学農学研究科・中村公人講師

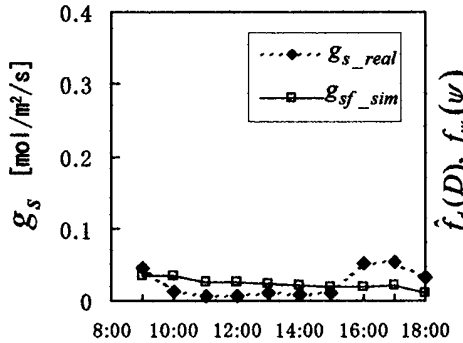

時刻 [h]

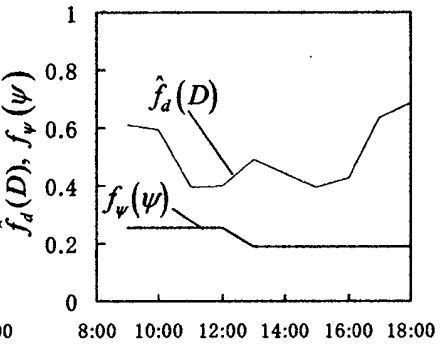

時刻 [h] (a) $8 / 29$
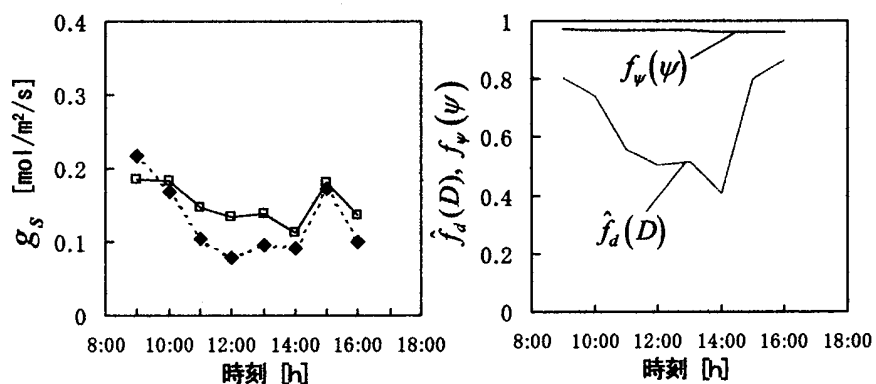

(b) $9 / 9$

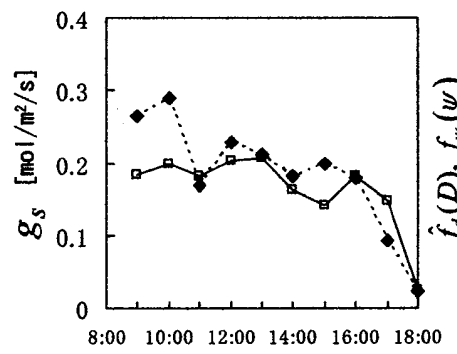

時刻 [h]

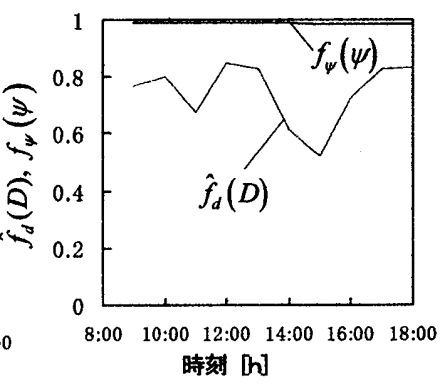

(c) $9 / 12$

図 $10 g_{s \psi_{-} \sin }$ と $g_{s_{-} r e a l}$ ，ストレス係数の経時変化 $(8 / 29,9 / 9,9 / 12)$
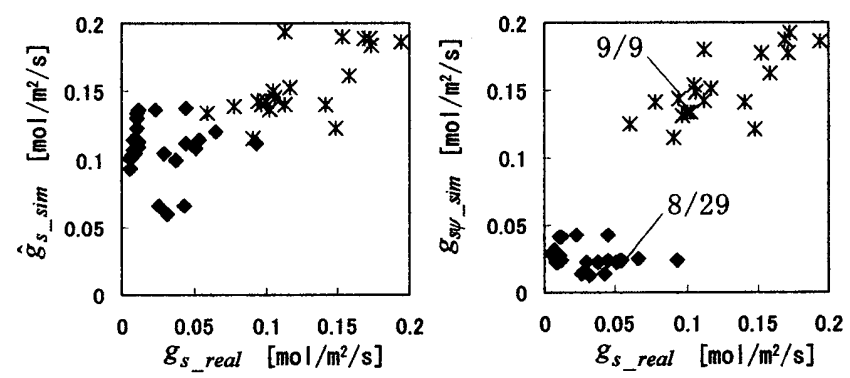

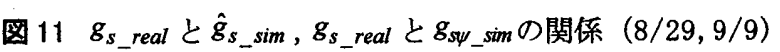
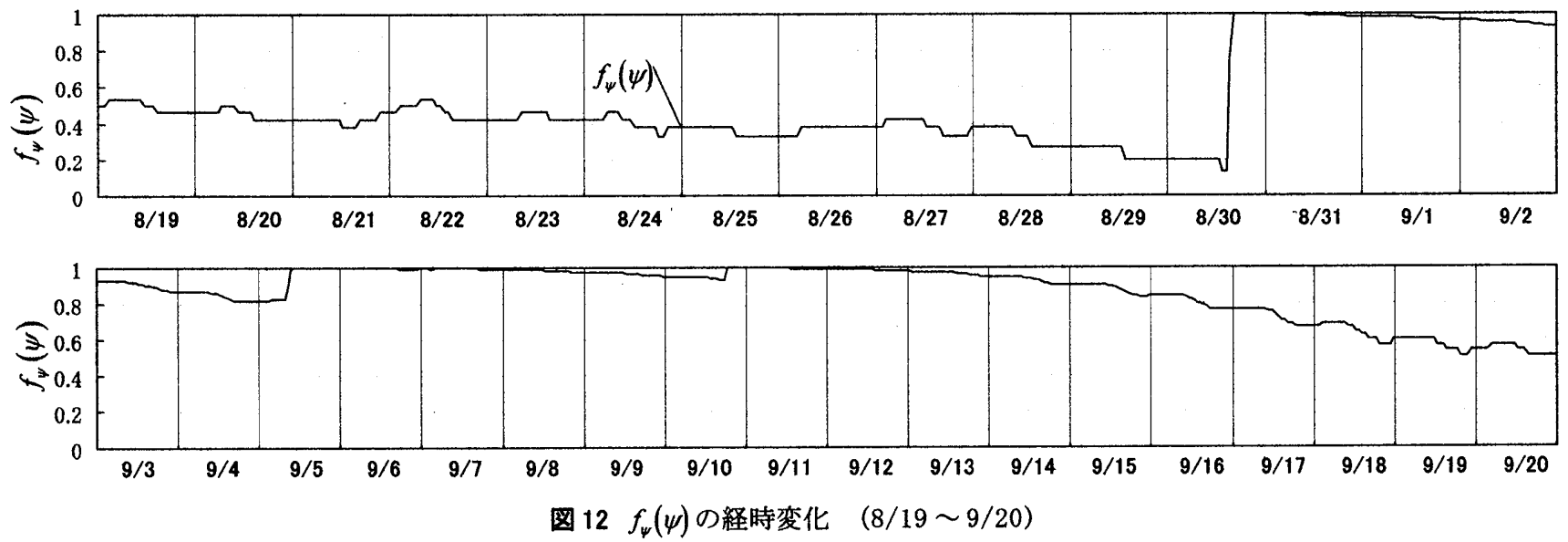
に土壤水分特性の実験方法等の指遒を受け，京都大学蹗学研 究科・小杉緑子助手には気孔コンダクタンスに関して助言を 受けた。また, 本研究の一部は, 平成 15 年度財団法人みずほ 学術振興財団（代表研究者：佐藤愛）の助成を受けた。ここ に記して感謝の意を表します。

\section{注}

注 1 ）実測地の土壤の物性值を表 I に示す。含水比は含水比試 験, 土粒子の密度は密度試験, 飽和透水係数は変水位法 による測定，粒度分布は粒度試験をそれぞれ行い求めた。 粒度分布は磁 $39 \%$ ，砂 $48 \%$ ，シルト $10 \%$ ，粘土 $3 \%$ であっ た。粒径が広い範囲にわたって分布し，締固め特性の良い 土といえる11)。

注 2) パラメータ同定には, U.S.Environmental Protection agency が 開発したソフトを使用した。

注 3 ）娄場容水量時とは, 多量の降雨もしくはかん水し, 重力に よる水の下降運動が小さくなった時をさす。ただ，重力 による水の下降運動が小さくなる時点を決めにくいので, 一般に, 降雨後やかん水ののち 24 時間後とする。

\section{本䜽文に関する既発衰詇文}

a ）花平愛，吉田治典：土㗧水分ストレスを考慮した気孔コンダ クンタンスモデルに関する研究，日本建築学会大会学術講 演梗概集，D-1，pp.639-640，2006.9.

\section{參考文献}

1）佐藤愛, 吉田治典, 伊藤麻美子, 村上大輔：集合住宅の 住棟間における樹木の気候緩和効果に関する研究，日本 建築学会環境系論文集, No. 587, pp.79-85,2005.1

2) P.G.Jarvis : The interpretation of the variations in leaf water potential and stomatal conductance found in canopies in the field, Phil.Trans.R.Soc.Lond.B.273, pp.593-610, 1976

3）檜山哲哉, 高橋厚裕, 橋本哲, 福嶌義宏: 落葉 - 常緑広葉 樹から構成される二次林の気孔コンダクタンスの日変化と 季節変化, 水文・水資源学会誌, Vol.16, No.2, pp.113130,2003

4) Davies, W.J. and Zhang,J.H.: Roots signals and the regulation of growth and development of plants in drying soil , Annual Review of Plant Physiology and Plant Molecular Biology, 42, pp.55-76, 1991

5）佐藤愛, 吉田治典, 伊藤麻美子, 村上大輔：温熱環境改善 のための樹木の蒸散作用モデルに関する基礎的研究，日本 建築学会環境系論文集，No. 598,pp.71-77，2005.12

6) W. Larcher 著: 植物生態生理学, シュプリンガー・フェア ラーク東京, 2004

7 ) 新田伸三著：環境緑地(2)一植栽の理論と技術，鹿島出版会 1999

8 ) 花平愛, 吉田治典: 常緑広葉樹と落葉広葉樹の気孔コン ダクタンスモデルに関する研究, 建築学会環境系論文集, No. 608 , pp. 105-111,2006. 10

9 ）ダニエル・ヒレル著：環境土噀物理学, 農林統計協会, 2001

10 ）中野政詩, 宮崎毅, 塩沢昌, 西村拓著：土壤物理環境測定 法, 東京大学出版会, 1995

11 ）安川郁夫編：土質試験一基本と手引き，社団法人地盤工学 会, 2005

12 ）諸泉利阙，昢野治彦，丸山利輔，佐藤裕一，佐藤幸一：野 外における不飽和土壤帯中の熱・水分移動特性, 水文・水

\section{表 I 土䘫の物性值}

\begin{tabular}{|c|c|c|}
\hline & $-10 \mathrm{~cm}$ & $-30 \mathrm{cr}$ \\
\hline 和透水係数 $[\mathrm{cm} / \mathrm{s}]$ & $3.2 * 10^{-3}$ & $2.4 * 10^{-2}$ \\
\hline$[\mathrm{cm} 3 / \mathrm{cm} 3]$ & 0.37 & 0.334 \\
\hline 軾㩧密度 & 1.36 & 1.44 \\
\hline 含水比 [\%] & - & 16.4 \\
\hline 粗子の密度 $[\mathrm{g} / \mathrm{cm} 3]$ & - & 2.61 \\
\hline
\end{tabular}

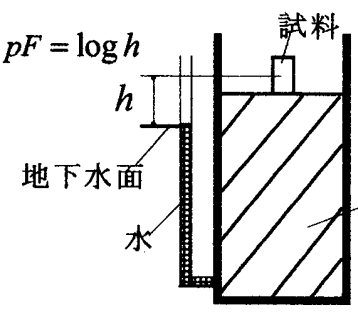

(1) (1) 土柱法
細砂
資源学会誌, Vol. 10,No. 1, pp. 20-31, 1997

13) Stewart, J.B. :Modelling surface conductance of pine forest, Agri. For. Metorol, 43,pp.19-35, 1988

14 ）小杉緑子，小橋澄治，柴田昌三：数種常緑広葉樹におけ る気孔コンダクタンスのモデル化，日本緑化工学会誌， Vol. 20, No. 3, pp. 158-167, 1995

15) Hanan, N.P. and Prince,S.D. :Stomatal conductance of West-Central Supersite vegetation in HAPEX-Sahel:measurements and empirical models, J.of Hydrology , 188-189,pp.536-562, 1997

appendix 1

土壌の乾燥による水分ストレスが要因となって気孔が閉 じた場合の測定例を図 I に示す。

appendix2

$\theta$ と $\psi$ の関倸を求める実験は, $p F$ の値によって実験方法 が異なる (表 II 参照)。今回の実験では, $p F$ は $0 \sim 6$ までの らち 14 点とした。(1)土柱法は, 細砂を充填した土鏆カラム の上に試料をおき，はじめ飽和状態にした後，所定の地下 水位（地下水面から供試土壤の中心までの距離 $h$ ）になる ように排水してやり，24時間後に，供試体の含水比を測定 する方法である（図 II 参照）。(2)吸引法は，「一定の負圧の 蒸留水を土中水に接触させ, 間隙水の負圧が平衡するまで （24 時間）排水させ，供試体の含水比を測定する方法であ る10) 1。(3橾心法は，「供試体を回転ドラムの中に入れて一 定の回転数で回し，一定の重力を試料に与えて脱水平衡さ せ，その重力に対応したポテンシャルと試料の含水比を求 める $\left.{ }^{10}\right)^{\prime}$ 」。(4)蒸気圧法は「一定温度の密閉容器内に一定濃 度の溶液と試料を 1 ケ月ほど置き，試料の質量と含水比を 測定する ${ }^{10)} 」$
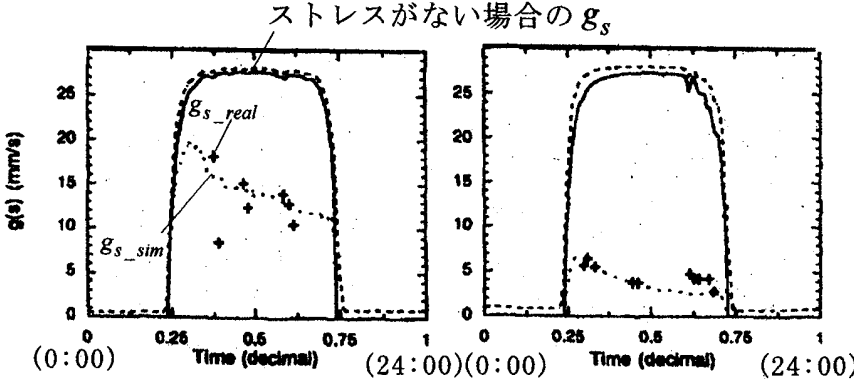

（a）土壌が湿潤の場合 十は実測値,

（b）土壤が乾燥の場合

一はストレスがないとして推定した值

図 I 土壤の乾燥によって気孔閉鎖が生じた例13)
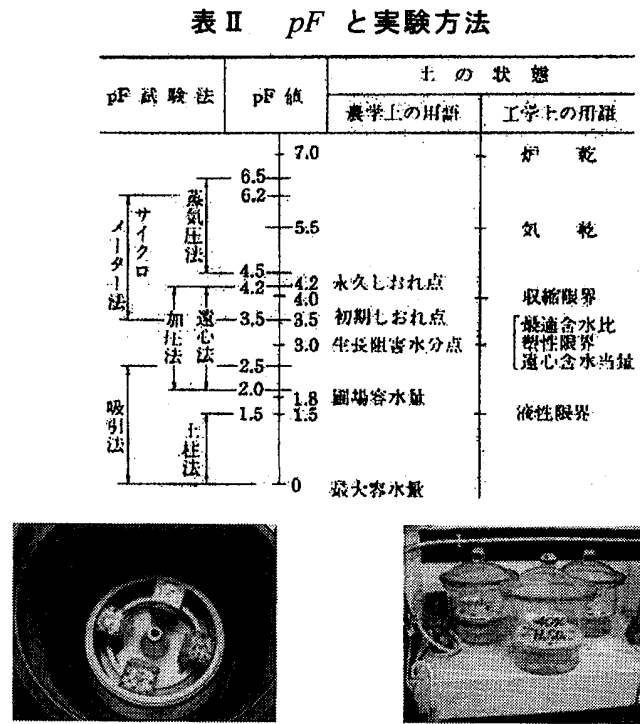

（2）(3) 遠心法 図 II 試験の模式図と写真

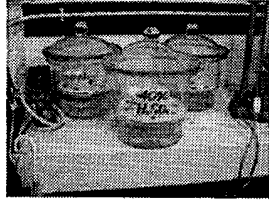

（3） (4) 蒸気圧法 